\title{
The marketing of apples produced in Chihuahua, Mexico against the American Giant: a case of dumping
}

\author{
T. de J. Perez-Chavez, E. G. Anchondo-Aguirre, \\ J. L. Coronado-Quintana \& M. A. Paredes-Aguirre \\ Full time Professors, College of Business and Management, \\ Autonomous University of Chihuahua, Mexico
}

\begin{abstract}
The State of Chihuahua is the largest producer of apples with about $50 \%$ of Mexican production. The objective of this paper is to discuss the procedure followed up by Mexican authorities who brought this issue up to international law as a case of dumping and to examine the implications of apple marketing in Mexico. In 1992, the Mexican apple growing union with headquarters in Chihuahua, detected apple importations coming from the United States of America at a price far below the price charged in the domestic market. As a consequence, the Mexican Secretariat of Commerce and Industrial Foment (SECOFI) initiated a dumping investigation in 1997 regarding the trade of apple imported from the United States of America into Mexico. The International Trade Commission reviewed the Mexican petition and agreed that dumping was made in apple importations. In August 2002, Mexico's SECOFI announced its decision to cancel the 1998 U.S./Mexico apple dumping suspension agreement. Therefore, the SECOFI resumed the anti-dumping investigation, which began in 1997. The analysis concerning the apple marketing is vital to apple growers in Mexico as a way to understand their rights and to be aware of existing procedures that ensure fair competition.
\end{abstract}

Keywords: dumping, anti-dumping, Chihuahua, Mexico, apple.

\section{Introduction}

Unfair practices in international commerce can affect producers in several countries, as is the case of dumping. The term "dumping" identifies the action 
through which a business sells a product to a foreign country at a price that is less than what it is sold for in its country of origin [1]. For example, the United States Department of Commerce sustained the case of apple concentrates imported from China, which were offered at $52 \%$ less the cost of production in their country [2]. Recently, the US-Department of Commerce initiated an antidumping investigation concerning light paper from China, Germany and Korea [3] alleging dumping percentages of $108 \%$ for China, $29 \%-75 \%$ for Germany and $40 \%-65 \%$ for Korea.

In the state of Chihuahua, Mexico, UNIFRUT (Union Agricola Regional de Fruticultores or, the Regional Agricultural Union of Fruit Producers) which is a Civil Association has detected dumping-like imports of apples since 1992. These imports into Mexico originated in the United States with prices clearly inferior to their normal value in their domestic market. In addition, UNIFRUT presented a petition before SECOFI, (Secretaria de Comercio y Fomento Industrial or, the Secretary of Commerce and Industrial Foment) so that an investigation into dumping could be conducted [4]. This way, compensatory dues over the import of this product can be controlled [5,6]. This action by UNIFRUT was important and necessary when considering that Chihuahua exports approximately $60 \%$ of apples produced in Mexico [7] and that their product is excellent in terms of quality, color and flavor.

The apple production in Chihuahua is a consolidated industry that generates extensive manual labor and is essential for the state economy. At present, there is no published information over the mechanism and preceding practices of dumping that were introduced in the case of apples produced in Mexico. The recent study demonstrates that fresh apple exports from the United States into Mexico exercises dumping-like activity. Another objective was to analyze the potential damage to the national production of apples. The results allow producers in established states such as Chihuahua, Puebla, Zacatecas, Durango, Queretaro, Coahuila and Nuevo Leon to know that they are protected by international laws and that the Mexican government can help them legally in cases of dumping.

\section{Learned legal actions}

UNIFRUT presented before SECOFI an estimated margin of discriminatory price for the fraction of tariffs or customs 0808.10 .01 that appears on the tariff of the General Import Tax Law. Because the products classified under these fractions are not homogenous but different, UNIFRUT proceeded to define the product codes considering two criteria; apple type and apple size using the Golden Delicious and Red Delicious varieties. After combining several criteria, 14 product codes were identified and the normal value calculated based on the domestic market price in the United States. The product price was obtained by weekly quotes published in the Federal State Marker News. Likewise, UNIFRUT established the normal weekly value for each product code during the investigation period. The SECOFI admitted that the method used by UNIFRUT utilized the estimate of normal value since consideration was congruent with the 
established depositions in article 31 of the Exterior Commerce Law (Ley de Comercio Exterior, 2005) in number 2.1 that specifies the relative agreement to the application of Article VI of the General Agreement over Tariff Customs and Commerce (Articulo VI de Acuerdo General sobre Aranceles Aduaneros y Comercio, AGAAC, 1994) as well as article 39 of the same law that defines the damage that can be caused to the national industry. Based on the pediments of importation, SECOFI found revenue of Golden Delicious and Red Delicious varieties similar to national apples. Several fresh varieties are used for human consumption.

\section{Repercussions in the national market}

The petition that UNIFRUT presented to SECOFI explained that the national production of apples was being constant with time (Figure 1); nevertheless, the price of apples reached the lowest level or the price increments were insignificant. Figure 1 notoriously shows that in 1995 Chihuahua produced about 11.5 million (box of $20 \mathrm{~kg}$ ) apples and this production has been more or less constant with time. UNIFRUT explained that the low price level was due to imported apples which did not allow major increases. Therefore, apple importation has a direct consequence that damaged national producers. Clearly, the presence of low cost imports distorts behavior in the national market [5]. Moreover, the Figure 1 shows the price of the Red Delicious and Golden Delicious apples in the same period (1992-1998) where it is evident a low price in 1995.

\section{Dumping and dumping margin}

Dumping is when one country's products are introduced to another country's economy at a price far below the normal price in the country of origin [1]. The normal value of the product is the price offered in the domestic country. In the event that the normal value cannot be obtained, two actions can be taken; to consider the price at which the product is offered in a third country and/or estimate the production cost in the country of origin. Aside from normal value for a dumping analysis, other factors considered are product quality and the credit and conditions of the sale [1].

It is interesting to note that the practice of dumping per se, should not be considered immoral or illegal since producers can offer their products at different prices and in different markets. Nevertheless, this practice should be condemned if it threatens or causes material damage to the established industry in a country. The elements of dumping are a product being sold in a country at a lower cost than its country of origin, the potential material damage to the domestic product and the causal alliance between both events. On the other hand, anti-dumping measures should justify and exercise action only when any of these two elements unite. The dumping margin refers to differences between normal product value and the price of exportation of said product. This margin is established under two schemes; the first one is considering the average normal values in 
comparison with the average price of exportation, while the second is analyzed through the comparison of normal values with exportation prices obtained from realized transactions. The dumping margin is normally expressed as a percentage of the export price.

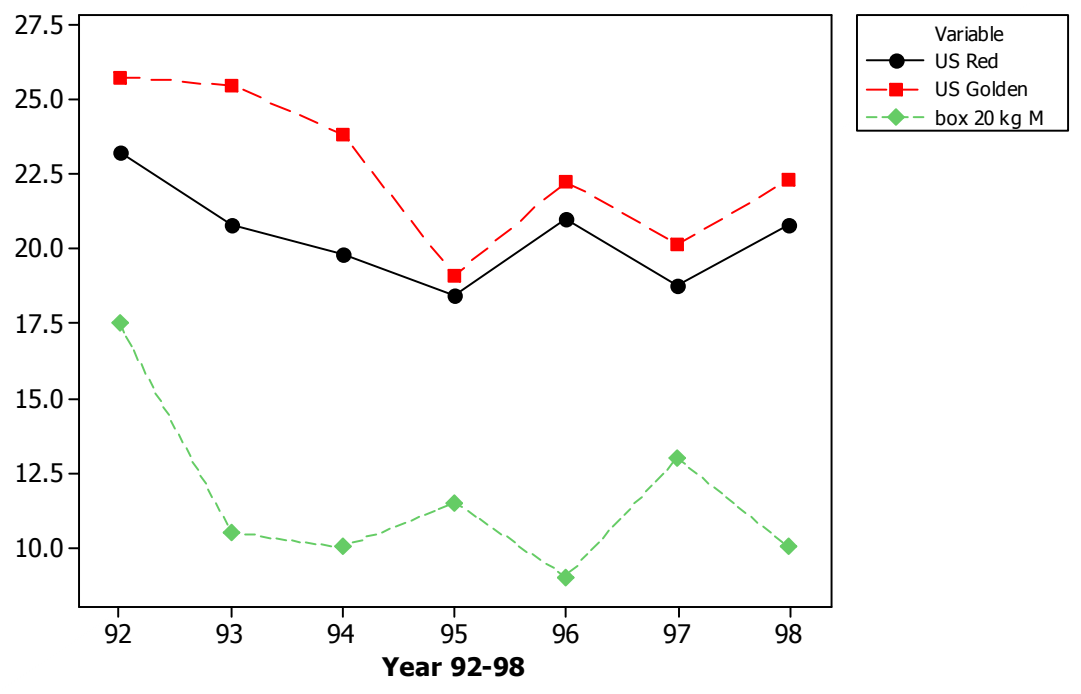

Figure 1: Apple production and price of two apple varieties in the State of Chihuahua, Mexico (1992-1998).

The World Trade Organization (WTO) condemns and restricts unfair and unjust commercial practices which generally take the form of dumping or subsidiaries. Dumping represents a fundamental distortion of basic international commerce. With exception to other obligations of GATT, they authorize a country to impose anti-dumping taxes to compensate for this unfair practice if it has caused material damage to the domestic industry. Such taxes are imposed based on the dumping margin. Although the concept of dumping is relatively simple, very complex computations are needed to adjust the factors that affect export price and normal value to make two comparable prices.

It is important to mention that Mexico just lost a dispute regarding "zeroing" with the United States. Zeroing describes analyzing the two potential stages of a dumping analysis [8]. In the first stage, a product's price in the country of origin is lower than the market price, which constitutes dumping. In the second stage, higher market prices can be specified in a country of origin at the market and consequently, dumping is not confirmed. In the case of non dumping, the commerce would assign a value of zero to this comparison, which explains zeroing, which does not utilize negative numbers.

Recently the tendency towards globalization has forced unilateral and multilateral countries ways to decrease the customary standards of imports. This induces producers to be competitive with products of other countries and consumer preference. Yet, on occasion these policies have motivated the 
execution of unfair practices of some countries in which the majority of cases are governed by the state, as in the case of China where costs are subsidized on a grand scale.

The financial and economic impact of dumping is evaluated when there is a reduction of product, lost sales, reduced utilities, market loss, decreased productivity, a reduced turn of investment, negative price effects and other aspects.

\section{Anti-dumping legislation}

Every country has tried to counteract these unfair practices in their policies with anti-dumping legislation. These measures strive to protect their domestic and regional industries and therefore, their national producers. New York apple growers in the United States lost about 81 million dollars through unfair commercial practices with apple juice which originated in China in 2002 [9]. It is evident that developed countries benefit the most at the cost of poor or underdeveloped countries. This is true because the developed countries introduce their products at less cost and consequently at a low price, due to their economic scale. On the other hand, damaged countries impose special custom barriers (tariffs) on imported products, establish some payment for exportation rights and create the payment of national subsidies, all this trying to protect their national economy.

It is a well documented fact that the United States supports their agricultural growers with high subsidiaries. This brings about high production in their country of origin and dumping in poor countries or those less competitive. In relation to market access, the gain of agricultural liberty is due in large part to financial intermediaries and not to poor countries or growers. Yet larger, developing countries can win. In spite of being under pressure, northern countries still insist upon their subsidiary regimens. While producers benefit from taxes against foreign competitors that proportion similar products at a reduced cost, consumers are forced to buy products at a higher internal price. As such, anti-dumping measures impose one of the highest costs of welfare of either commercial measure in the United States. Since Canadian producers frequently use this measure, there is no reason to believe the impact of Canada is any different. Given these significant implications to welfare, creative solutions to reduce the frequency of anti-dumping measures should be realized and can be executed with an order to prevent additional welfare loss.

Even though anti-dumping rights have a negative economic effect, this measure continues to be the preferred mechanism of protection of national industry in many industrialized countries. Traditionally, the determination of damage and the right has been a three part process; the participation of denouncing national production, the infringing of foreign products and the government. The Canadian government in its only anti-dumping deposition has special import measures that permit the consideration of public interest after duties have been imposed. This consideration to public interest could allow mitigation or suppression of functions. 


\section{Dumping regulation according to free commerce}

Historically, this disposition has been used in limited circumstances and has not been translated to the overwhelming decrease of anti-dumping rights. The limited use of this disposition is due to political economic theory, particularly the support of production and tariffs in the form of functions. Through an economic political analysis, an interested party would have to demonstrate public interest in the Canadian tribunal of international commerce in favor of producers through a series of financial avenues and proceedings. Yet, the economic political analysis also suggests that many consumers have the power to persuade the tribunal to diminish the rights in defense of their interests with greater energy.

In the United States, the anti-dumping administration is run by the International Trade Administration (ITA) of the Department of Commerce and for the International Trade Commission (ITC). At the first level, the ITA determines if dumping has occurred through analysis of the products that have been sold in the United States at a less than normal price. In those cases in which market economies are implicated, ITA uses the price of the country of origin to determine the product normal value. This is the fair market value of the product or similar products in the domestic market of the foreign company. Once ITA determines that dumping has occurred, it first establishes a dumping margin adding the normal value price of exportation.

In the latter part of the analysis, ITA determines if the national or local industry has suffered material damage as a result of dumping. For this purpose, ITA sends questionnaires to those industry companies to collect information pertaining to damage or other pertinent information. If ITA's resolution over damages is affirmative, they in turn continue their preliminary investigation concerning dumping by sending questionnaires to all other interested parties including foreign exports and domestic imports [10]. These questionnaires collect detailed information concerning prices as well as additional information that can be used to adjust them since the export price and the country of origin are compatible. In this manner, if ITA determines based on those questionnaires that dumping occurred, ITA will amplify the investigation over the damage issue. Furthermore, in the case ITA confirms the existence of material damage; it makes the final decision over the issue, establishes the dumping margin and imposes anti-dumping taxes according to all these manoeuvres.

\section{One decision, the first of its type, of a Federal Court of appeals}

The United States presented various cases of dumping during the 1970s. Japan was accused of dumping steel and televisions while European car makers were also accused of dumping in the sale of automobiles. To avoid grave compensations, the majority of these producers decided to increase their prices. Subsequently, the United States adopted to retaliate by dumping semiconductor circuits on behalf of the European car makers. The most recent case also exists in the United States in respect to accusations against Mexico and Venezuela over 
petroleum dumping, which incurred many conflicts to determine that effectively, there had been damage to production.

\section{Concentrated orange juice: a case}

There are four principal producers of orange juice in Brazil; two are of Brazilian capital, one is of European and the other American. Orange juice is not consumed in Brazil, only fresh oranges are eaten which is why the majority of orange juice is destined for export. Until 1980, the demand for orange juice in the United States was satisfied wholly by national producers. But beginning in the 1980s, when there were a few bad harvests in Florida, the main orange producer, national producers were unable to cover the demand. This presented Brazil with an opportunity to export half of their orange juice production to the United States. A group of Florida producers presented an anti-dumping demand. Once the investigation was initiated, the growers realized that since Brazil did not consume orange juice, there was no presentative price. Pricing in a third country was not available either because Europe, another grand consumer, and the United States utilize the same pricing due to arbitration. A cost then had to be determined which included the price of the oranges, the costs of the industrial process plus a reasonable, beneficial margin.

It is important to note that two national drink producers, Proctor \& Gamble and Coca-Cola, opposed the petition since they were large consumers of orange juice concentrate which is used in the production of their drinks. These companies considered that an anti-dumping right would elevate their costs. The decision was difficult because the growers had to be favored without excessively damaging the drink producers. Both objectives were obtained.

\section{The UNIFRUT}

Few sectors are as organized and forceful as the fruit growers of UNIFRUTChihuahua, Mexico. This organization represents 20 local associations that have approximately 2,500 producers that control an area of an estimated 30,000 ha of apple trees. In 2004, they produced nearly 18 million boxes of apples $(20 \mathrm{~kg})$ that represented two thirds part of the total production of the entire country [11]. As a result of the judgment of dumping against North American apples that arrive in Mexico invoiced below production costs, in September 1997 they obtained a compensatory quota of $101 \%$. This obligated North American exporters to propose a price compromise based on \$11.46 US dollars for each 42 pounds box. The Mexican government and UNIFRUT accepted the compromise but then North American growers did not fulfil their promise by selling the imports at below the established price. It would be irresponsible not to mention that the United States being Mexico's principal commercial partner, produced in 2007 approximately 155 million boxes of apples, each weighing $42 \mathrm{lb}[4,12]$.

UNIFRUT demonstrated before the Secretary of Economy that the price compromise did not represent the "packed" price for which two protective policies were interposed. Yet the Secretary did not relinquish their protection of 
American exporters. Finally, the verdict in the dumping process was won by the Mexican producers and since August 2002 a compensatory quota has been established of $46.58 \%$ for the most common varieties imported from the United States.

Armed with their triumph, apple growers in Chihuahua achieved high investments to modernize their production. Protective hail mesh was installed and they increased their refrigeration capacity in a controlled atmosphere exceeding their previous tonnage from 40,000 to 112,000. A good part of the investment was possible with the support of Allianza para el Campo (the Farm Alliance), a government dominated program.

The apple business in Chihuahua employs approximately 12,000 permanent employees and about 2 million additional laborers per year. In addition, they continue their juridical bouts in dynamic form; as in the revision of the compensatory annual, three neutral judges before the Fiscal Tribunal of the Federation and a panel before North American Free Trade Agreement (NAFTA; TLCAN in Spanish).

In response to UNIFRUT's actions, American exporters and Mexican importers have not stood idly by. They interposed 30 protections, of which 25 have resulted favorably to UNIFRUT. We should specify that one of those protections was lost by errors of the Secretary of the Economy. Nevertheless, in September 2004, the American exporters once again proposed a price conference like the one established in 1998. UNIFRUT rejected the idea based upon past experience; there was no sincerity among the Americans and lack of mechanisms within the Mexican government to meet the agreement.

\section{Conclusion}

The practice of Mexican apple dumping by the United States market affected producers' interest and the established industry. The decision by the international tribunals guarantees impartiality to protect the producers' interests, many of whom live in countries of varying degrees of development.

\section{Acknowledgements}

The authors would like to express appreciation to the Regional Agriculture Union of Fruit Producers (UNIFRUT-Chihuahua) for the information provided. In addition, we are very grateful to the College of Business and Management of the Autonomous University of Chihuahua whose staff and General Director actively and significant contributed to this manuscript.

\section{References}

[1] Owen, V.CH.Jr. 1999. An introduction to trade remedies available under U.S. Law. Wiley Rein http://www.wileyrein.com/publication.cfm? publication_id=8009 
[2] AP, 2000. Associated Press. 2000. Ruling: US apple producers harmed; (5 edition). Journal of Commerce, New York, May 17, 2000

[3] DC, 2007. Department of Commerce. International Trade Administration. Fact Sheet. http://ia.ita.doc.gov./download/factsheets/factsheets-lwtp-init103007.pdf

[4] DiBenedetto, B. 2006. Growers fight apple export barriers; The Journal of Commerce Online Edition. Journal of Commerce. Retrieved January 16, 2008 from ABI/INFORM Global database. Document ID: 1127802721

[5] DOF, 1997. Diario Oficial de la Federación. Mexico, D.F

[6] USDA, 1997. Mexico; Antidumping investigation against U.S. apples. USDA Agricultural Trade Reports. Retrieved January 17, 2008 from ABI/INFOR; Trade \& Industry database. Documents ID: 104976312

[7] SAGARPA, 1995. Estadisticas de la Secretaria de Agricultura, Ganaderia, Desarrrollo Rural, Pesca y Alimentación. Mexico DF

[8] Schwab, S.C. 2007. United States Wins WTO "zeroing" disputes with Mexico. Office of the United States Trade Representative. http://www.ustr.gov/Document_Library/Press_Releases/2007/December/U nited_States_Wins_WTO_Zeroing_Dispute_with_Mexico.html

[9] Schumer, Ch. E. 2002. Schumer: New US commerce dept plan could cost NY apple growers millions of Dollars. United States Senate http:www.senate.gov/schumer/schumerwebsite/pressroom/press_release/PR O1197.html

[10] DiBenedetto, B. 2005. Mexico lifts apple tariff; The Journal of Commerce Online Edition. Journal of Commerce. Retrieved January 17, 2008, From ABI/FORM Global database. Document ID: 851243971

[11] UNIFRUT, 2007. Union Regional de Fruticultores del Estado de Chihuahua. Estadisticas basicas del estado

[12] WHT. 2002. World Horticultural Trade \& US export opportunities http://ffas.usda.gov/htp/Hort_Circular/2002/0211/Stats/NORTHERN\%20H.pdf 